\title{
Income diversification of migrant colonists vs. indigenous populations: Contrasting strategies in the Amazon
}

\author{
Cristian Vasco Pérez ${ }^{\mathrm{a},{ }^{*}}$, Richard Bilsborrow ${ }^{\mathrm{b}}$, Bolier Torres ${ }^{\mathrm{c}}$ \\ ${ }^{a}$ Facultad de Ciencias Agrícolas, Universidad Central del Ecuador and Universidad Estatal Amazónica, Ecuador \\ ${ }^{\mathrm{b}}$ University of North Caroline at Chapel Hill, USA \\ ${ }^{\mathrm{c}}$ Universidad Estatal Amazónica, Ecuador
}

\section{A R T I C L E I N F O}

Article history:

Received 2 April 2015

Received in revised form 22 August 2015

Accepted 13 September 2015

Available online $\mathrm{xxx}$

\section{Keywords:}

Off-farm employment

Diversification of livelihood strategies

Mestizos and indigenous populations

Household survey

Amazon

Ecuador

\begin{abstract}
A B S T R A C T
How do migrant colonists and indigenous populations differ in their land and labor allocation in the Amazon, and what does this imply for their income levels/livelihoods and the environment? We address this by analyzing patterns of on- and off-farm employment of rural populations, both mestizo and indigenous, in the Ecuadorian Amazon. We use data from an unusual survey that covers both mestizo and indigenous households. As elsewhere in rural areas of the developing world, off-farm employment is found to be the principal income source for $68 \%$ of the population and accounts for $53 \%$ of total household income on average. Within off-farm employment, farm wage employment is most common for the poor, who usually have little human (education) or natural capital (agricultural land). For educated individuals, in contrast, non-farm wage employment is commonly the choice. In the Amazon, the government (national, provincial, municipal) is the main employer, which is linked to recent large government investment in infrastructure and decentralization, leading to significant expansion of nonfarm employment opportunities for rural populations close to major towns. The implications of this for livelihoods, sustainable development and the environment are explored in the conclusions.
\end{abstract}

๑) 2015 Elsevier Ltd. All rights reserved.

\section{Introduction}

How do the very different types of peoples living in the remote rainforest of the Ecuadorian Amazon survive? That is, what livelihood strategies do they adopt, do these differ between indigenous populations and mestizos who migrate to the region as colonists from elsewhere in the country? In particular, do they differ in their dependence on agriculture, the resources of the forest and rivers, and off-farm work? And finally, what are the implications for household levels of living and the future survival of the rainforest?

For some decades now, off-farm employment has become one of the main income sources for rural people in developing countries (Anderson and Leiserson, 1980). This is often true even in remote areas where people still rely heavily on environmental and forest income (Angelsen et al., 2014; Wunder et al., 2014). But is this also true in the Ecuadorian Amazon?

\footnotetext{
* Corresponding author. Universidad Central del Ecuador, Facultad de Ciencias Agrícolas, Gerónimo Leiton y Av. La Gasca s/n, Ciudadela Universitaria, 170521 Quito, Ecuador

E-mail addresses: clvasco@uce.edu.ec (C. Vasco Pérez), richard bilsborrow@unc edu (R. Bilsborrow), boliert@yahoo.com (B. Torres).
}

The Ecuadorian Amazon, one of the world's biodiversity hotspots (Bass et al., 2010; Myers et al., 2000), is under threat from a number of factors, including, on the one hand, in-migration, frontier colonization and the advance of the agricultural frontier, and on the other oil, mineral and timber exploitation (Hicks et al., 1990; Bilsborrow et al., 2004). Because of factors such as isolation from city centers and markets, lack of agricultural extension assistance to farmers, and low fertility, acidic soils, agricultural incomes in the region are likely to be lower than in the Highlands and on the Coast, the other two geographical regions of Ecuador (Vasco and Vasco, 2012). The situation is further complicated due to rapid population growth and the resulting ongoing process of farm subdivision which has turned land into a resource which is no longer plentiful for farmers in the case of Ecuador (Bilsborrow et al., 2004), where its Amazon region may be considered a closed territory, first, circumscribed by the Andes mountains on the west and the borders of Colombia and Peru on the other three sides; and within this region, large areas were appropriated by the State to create three large national parks and protected areas while more recently even larger areas were titled to indigenous communities via common property regimes, in the early 1990 s. 
Despite prior studies, none has compared income levels or livelihood diversification patterns of colonist and indigenous populations in Ecuador or elsewhere in the Amazon. We address this gap by taking advantage of detailed data from a new household survey to analyze the drivers of off-farm employment and other livelihood strategies of colonist and indigenous (Kichwa and Shuar) populations in the Ecuadorian Amazon.

The rest of this paper is organized as follows: the next section presents the theoretical framework and hypotheses, followed by a review of the literature on livelihood strategies focusing on offfarm employment in the Amazon. The subsequent section introduces the study area, data source, and variables. Finally, the statistical estimation methodology is described, followed by the results and conclusions.

\section{Theoretical framework}

The rural household model (Ellis, 1993; Singh et al., 1986) is a useful starting point to examine income diversification decisions. Rural households may be seen to maximize their utility given a number of constraints, among them income, time and technology. The model posits that diversification is a function of the returns to labor time in on-farm employment compared to the returns from off-farm employment. With a fixed amount of initial assets (land, capital and technology) and household labor time, a household compares the returns from allocating labor to on-farm vs. off-farm work (each with several components), and rationally decides where to allocate labor (Ellis, 2000). Thus households or individuals tend to allocate labour to off-farm work provided it yields higher returns and is no more risky than farm activities (Reardon et al., 2000). The literature differentiates between risk management (ex ante) and risk coping (ex post) strategies (Ellis, 2000; Reardon et al., 2006). In the first, households choose to diversify income sources $a$ priori to prevent income failures at the household level, while in the second households diversify activities to cope with unexpected events that threaten their livelihoods. Evidently, the approach here draws on the first version, of Ellis and many followers.

In the case of the Ecuadorian Amazon, participation in off-farm employment may be driven by "push factors" such as declining soil fertility, low yields and small land holdings, which negatively affect agricultural incomes (Bilsborrow et al., 2004). In this line, Murphy (2001) notes that off-farm wages can compensate for low farm earnings resulting from small parcel size and isolation from markets. Nevertheless, partaking in off-farm employment may also be a consequence of "pull factors", including higher returns to off-farm employment, which is partly due to higher wages linked to wage levels offered by oil companies (Murphy et al., 1997), and more recently to the growing demand for employees due to decentralization and the growth of the public sector (Jara Alba and Umpierrez de Reguero, 2014; SENPLADES, 2012). The implications of this broad theoretical framework for hypotheses regarding the specific effects of sets of individual, household and community characteristics on the choice of main income-earning type of work a person engages in are presented in section 5.2 below.

\section{Literature review}

A number of studies have examined the diversity of livelihoodseeking behavior in developing countries, often focusing on the determinants of participation in off-farm work. In the case of Latin America, Berdegué et al. (2001) found that female-headed households in Chile with good education and access to credit are more likely to participate in non-farm work. Escobal (2001) found that education, credit, electrification and road infrastructure are important determinants of income diversification in Peru. Also in
Peru, Laszlo (2005) found that Peruvian households in districts with more population centers and a more developed tourist sector are more likely to engage in non-farm self-employment. Isgut (2004) determined that farm wage labor is principally undertaken by low-educated men. On the other hand, non-farm self-employment is common among women, while non-farm wage employment is carried out mainly by those more educated. In Nicaragua, Corral and Reardon (2001) found that educated men are concentrated in nonfarm wage employment, while both women and household heads tend to be self-employed. Ferreira and Lanjouw (2001) studied the determinants of non-farm work in Northeast Brazil, finding that well-educated men are more likely to engage in well-paid non-farm jobs, while women tend to undertake low-income non-farm jobs. Also in Brazil, Jonasson and Helfand (2010) found that the shorter the distance to population centers, the higher the odds for rural Brazilians to take part in non-farm work activities.

Several case studies have focused on off-farm employment in the Amazon. In a qualitative analysis on the Brazilian Amazon, for example, Steward (2007) noted that young people prefer off-farm jobs -mainly in the public sector-to agricultural jobs, the returns to which are considerably lower due to low market prices, lack of credit and lack of extension services. VanWey and Vithayathil (2013) found that the likelihood of taking part in off-farm work is higher for males, those more educated, and those residing closer to urban areas.

The determinants of land use of migrant colonists has been the focus of some considerable research in the Northern Ecuadorian Amazon (provinces north of Pastaza). Although these studies do not have off-farm employment as their focus, its importance is noted. For example, based on the first survey of 419 migrant colonist households in the Ecuadorian Amazon implemented by Bilsborrow and Pichon in 1990, Murphy et al. (1997) found that 36\% of colonist households in Sucumbíos and Orellana were engaged in some form of off-farm work, and that this was positively linked to household income and wealth. Pichón (1997b) observed that off-farm earnings of educated households are considerably higher than those with less educated household heads. Later Murphy (2001) argued that off-farm employment is a livelihood strategy of increasingly landconstrained colonists to cope with low harvests and drops in market prices (the price of the major cash crop, coffee, plummeted starting in the late 1990s). A second survey of colonist households was conducted in 1999 on the same approximately 400 plots of land and found the population had doubled. Research based on this second, much larger sample revealed changes over time in land use (increased deforestation) and labor allocation. Barbieri et al. (2005) reported that the share of households engaged in off-farm employment grew from about 30\% in 1990 to almost 50\% in 1999, seen as related to the reduction in farm sizes during 1990-1999 due to subdivision. Similar results are presented by Bilsborrow et al. (2004), who linked increasing off-farm work also to the growth of urban labor markets and improvements in infrastructure, especially roads, factors also noted by Rudel et al. (2002b) in the southern Ecuadorian Amazon.

Another relevant but small body of literature is that on off-farm employment of rural households in Ecuador. Using data from the Living Standards Measurement Survey (1995), Elbers and Lanjouw (2001) found that persons in the Amazon (albeit a small sample from the region) were less likely to participate in off-farm activities than those in the Highlands. In contrast, using data from the national Labor Force Survey -including 823 Amazon households(2010), Vasco and Vasco (2012) found that the likelihood of participation in non-farm work is higher for residents of the Amazon. Further research based on a more detailed new survey, such as that used here, is thus desired to clarify this.

In sum, the data suggest rising participation in off-farm employment in Ecuador over time. As in most developing 
countries, this seems to be the result of both push factors (e.g., population growth, smaller farms, declining soil fertility), and pull factors (e.g., improved roads and growth of urban labor markets). Given that these changes are occurring, what is the current status of indigenous and mestizo colonist households in terms of livelihoodseeking behavior? They have different endowments of land and labor (see descriptive data below) and very different cultures and connections to the land, but do these factors lead to very different forms of labor allocation? Or are other factors more central, such as education, household size, and location relative to markets? These are the central issues to be studied here, using data from a new, detailed household survey.

\section{Data and variables}

This section briefly describes the study area and the survey data. In addition, descriptive figures about on-farm and off-farm employment in Pastaza are presented and discussed.

\subsection{The study area}

Pastaza is Ecuador's largest but at the same time least populated province. Most of the population is concentrated in the western part, in the Andean foothills, while the far larger eastern part deeper in the Amazon is occupied mainly by indigenous populations. Colonists, coming principally from the highlands, represent 38\% of Pastaza's rural population, while indigenous peoples account for the rest, with the Kichwa and Shuar the most populous ethnic groups. The Kichwa are the most numerous, with an approximate population of 14,000 people. They hold communal land rights to approximately one million hectares of land. The Shuar number about 5000 individuals, and have communal land titles to about 200,000 ha in the southern part of Pastaza. The Shuar of Pastaza are mainly settled along the road going south from Puyo to Morona Santiago, the province where they originally migrated from (Fig. 1) (INEC, 2010; Prefectura de Pastaza, 2012). Population growth along with the advance of the agricultural frontier has resulted in increased pressure on natural resources in the province (ECORAE, 2003). As in most of the Amazon region, soils in Pastaza are very sensitive to erosion and become poor soon after vegetation is removed (Hicks et al., 1990; Mainville et al., 2006). As a consequence, yields are low compared to the Coast and the Sierra or Highlands regions of Ecuador. Given these limitations, farm households in the Amazon need to have more land to compensate for its low productivity, which leads them to clear more forest (when available); selling the timber is an added bonus that supplements household income in the short-run.

Most colonists engage in commercial agriculture, including crops such as coffee, cacao, African palm, sugar cane, palm heart, naranjilla (a native fruit) and taro (locally known as papa china), in addition to considerable, and growing cattle ranching. Although indigenous people practice subsistence agriculture (mainly cassava and plantains), many also engage in the production of cash crops which are marketed in Puyo, the provincial capital and by far the largest town in the Southern Amazon (Prefectura de Pastaza, 2012).

As noted above, population growth and scarcity of agricultural land have stimulated farm households to seek off-farm work (Bilsborrow et al., 2004), while the expansion of urban areas has opened up off-farm employment opportunities, facilitated by an improved road network. During the last decade, the Amazon has received significant government investments in education, health, electrification, and employment resulting from decentralization of public service, in the framework of the "Plan Nacional del Buen Vivir"

\footnotetext{
${ }^{1}$ Ecuador's National Development Plan 2013-2017.
}

(SENPLADES, 2013). These investments create non-farm jobs and dynamize local economies including the informal sector (Steward, 2007). However, many of the most highly qualified and better-paid positions in the Amazon are occupied by nonpermanent settlers coming from other regions of Ecuador (Vasco, 2013).

\subsection{The survey data}

The data used here come from a household survey conducted in the canton Pastaza, part of the province of Pastaza (see Fig. 1). The fieldwork took place in May-October 2013. The survey obtained information on household demographic characteristics, land use, household assets, and social capital, as well as on-farm and off-farm employment. Households were selected using two-stage sampling. First, given that resources were limited, only 17 communities could be selected (Fig. 1), so the procedure used was controlled sampling (Goodman and Kish, 1950; Kish, 1965), to ensure a broad diversity of communities in terms of ethnicity, distance to roads and markets, types of land tenure, population size and density, and the availability of off-farm and non-farm employment (see Cavendish, 2003). In the second stage, households within a community were selected using random sampling. A total of 304 households were selected in 17 sample communities (see Table 1). Although not a probability sample of communities, it ensures good representation of the diverse rural livelihoods in Pastaza. To illustrate, larger communities close to Puyo such as Canelos (Kichwa), Chubitayo (Shuar) and Simón Bolivar (colonist) offer more non-farm jobs since they concentrate some public sector functions including schools. Individuals residing in these areas are also more likely to commute to Puyo to engage in (mostly low qualified) non-farm jobs. Such jobs are not available in smaller communities relatively close to Puyo, such as Boayacu and Unión del Llandia (colonist), Pitirishka and Centro Yu (Shuar), where people rely more on cash crops. On the other hand, in Chapintsa and Sharupi (Shuar), and Santa Cecilia de Villano (Kichwa), where roads were opened recently and forested areas still exist, incomes from logging are likely higher than elsewhere. In settlements farther from Puyo such as Shiram Popunas (Shuar) and Killoalpa, Jaime Roldos and Nuevo San José (Kichwa), people tend to rely more on subsistence farming and forest products.

The data include Kichwa (116), Shuar (120) and colonist (68) households. The survey was administered to the household head and spouse (if available). The questionnaire seeks data on the involvement of household members in off-farm work and other economic activities based on data for 365 individuals from the 304 households who were at least 15 years old and had contributed to household earned/produced) income during the twelve months preceding the survey. It is important to note that income here is comprehensive, including the value of both subsistence and cash crops (including own-consumption), livestock, environmental income (mainly timber and game), and income from non-farm work. However, it excludes income from remittances, gifts, renting out animals, interest and other income from liquid assets, which in almost all cases are non-existent or tiny in these rural populations compared to their earned income. ${ }^{2}$

In this study, off-farm employment comprises farm wage employment, non-farm self-employment, and non-farm wage employment. Farm self-employment includes crop and animal production and raising fish in fish ponds. The common tendency to not include "environmental income" often leads to a misleading

\footnotetext{
2 Note remittances from former household members migrating elsewhere are non-existent or tiny since there are no migrants in the sample to international destinations.
} 


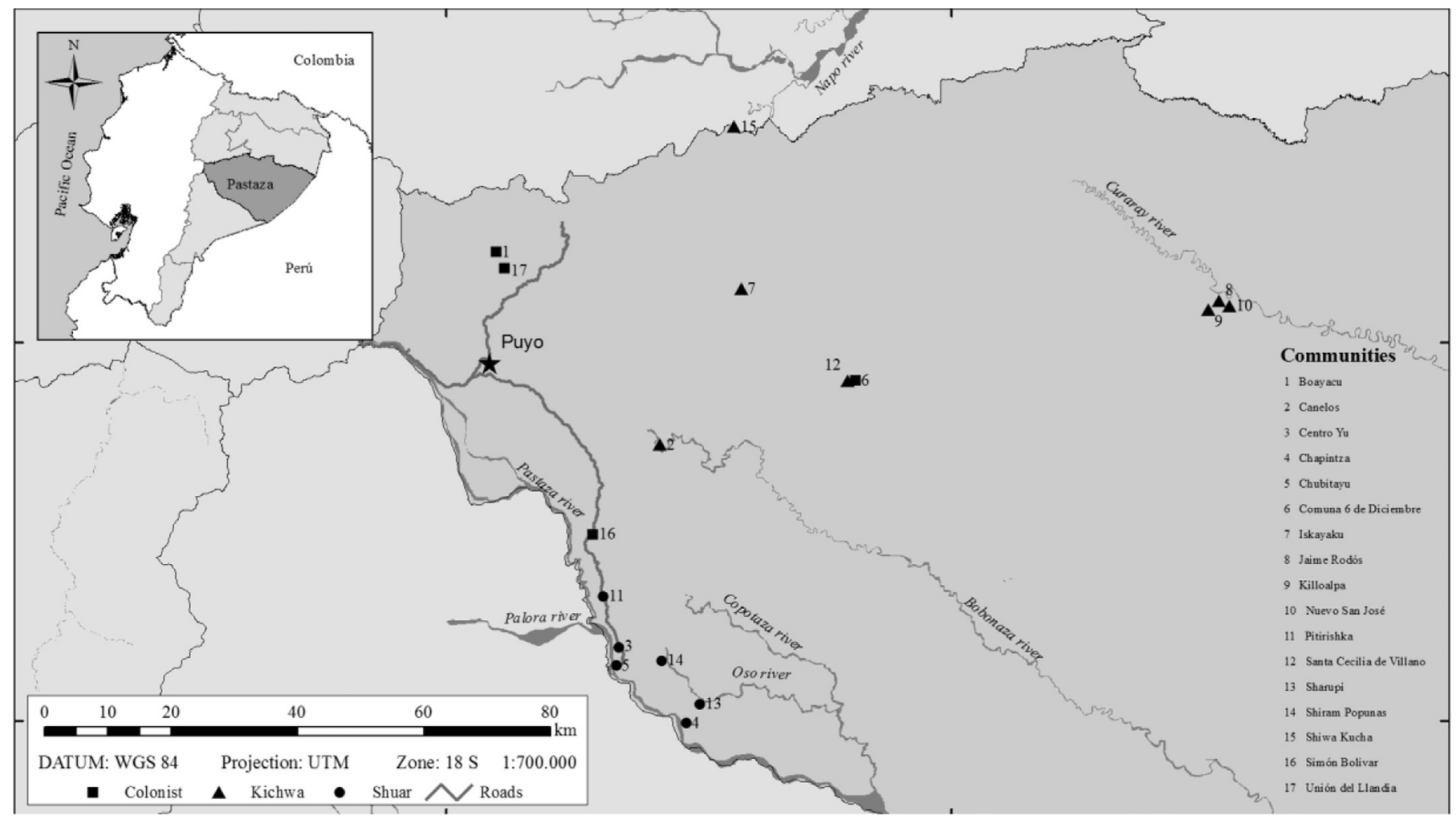

Fig. 1. The study area.

picture of rural livelihoods, especially in forested areas (Angelsen et al., 2014; Prado Córdova et al., 2013) where it is sometimes a significant part of household income. Thus in this study, income from environmental sources is included, and includes income from sales of products from timber extraction, hunting and fishing (in natural rivers, streams, and lagoons).

\section{Methodology}

This section describes the empirical strategy utilized to estimate the drivers of participation in the five livelihood strategies and presents the variables used in the multivariate analysis.

\subsection{Empirical strategy}

Since decisions regarding labor allocation are made simultaneously rather than individually, a multinomial probit model is used to estimate the likelihood of an individual participating in farm self-employment, generating environmental income, farm wage employment, non-farm self-employment, or non-farm wage employment as his/her principal source of income. A multinomial probit model is preferred over other approaches- -i.e., multinomial

Table 1

Communities included in the sample.

\begin{tabular}{|c|c|c|c|c|c|c|}
\hline Community & Population & $\begin{array}{l}\text { Predominant ethnic } \\
\text { group }\end{array}$ & Accessible by & $\begin{array}{l}\text { Time needed to reach } \\
\text { Puyo (hours) }\end{array}$ & Latitude & Longitude \\
\hline Comuna 6 de Diciembre & 45 & Colonist & Dirt road & 3.5 & $01^{\circ} 29^{\prime} 57^{\prime \prime} \mathrm{S}$ & $77^{\mathrm{a}} 28^{\prime} 19^{\prime \prime} \mathrm{W}$ \\
\hline Boayacu & 50 & Colonist & Dirt road & 1.0 & $01^{\circ} 18^{\prime} 53^{\prime \prime} \mathrm{S}$ & $77^{\circ} 58^{\prime} 56^{\prime \prime} \mathrm{W}$ \\
\hline Unión del Llandia & 180 & Colonist & Dirt road & 0.5 & $01^{\circ} 20^{\prime} 16^{\prime \prime} \mathrm{S}$ & $77^{\circ} 58^{\prime} 14^{\prime \prime} \mathrm{W}$ \\
\hline Simón Bolívar & 5682 & Colonist & Paved road & 0.5 & $01^{\circ} 43^{\prime} 09^{\prime \prime} \mathrm{S}$ & $77^{\circ} 50^{\prime} 43^{\prime \prime} \mathrm{W}$ \\
\hline Centro Yu & 50 & Shuar & Dirt road & 1.5 & $01^{\circ} 52^{\prime} 32^{\prime \prime} \mathrm{S}$ & $77^{\circ} 48^{\prime} 32^{\prime \prime} \mathrm{W}$ \\
\hline Shiram Popunas & 141 & Shuar & Trail & 6.0 & $01^{\circ} 54^{\prime} 00^{\prime \prime} \mathrm{S}$ & $77^{\circ} 44^{\prime} 54^{\prime \prime} \mathrm{W}$ \\
\hline Sharupi & 94 & Shuar & Trail & 3.0 & $01^{\circ} 57^{\prime} 45^{\prime \prime} \mathrm{S}$ & $77^{\circ} 41^{\prime} 39^{\prime \prime} \mathrm{W}$ \\
\hline Chapintsa & 420 & Shuar & Dirt road & 2.0 & $01^{\circ} 59^{\prime} 22^{\prime \prime} \mathrm{S}$ & $77^{\circ} 42^{\prime} 49^{\prime \prime} \mathrm{W}$ \\
\hline Pitirishka & 250 & Shuar & Paved road & 0.75 & $01^{\circ} 48^{\prime} 28^{\prime \prime} \mathrm{S}$ & $77^{\circ} 49^{\prime} 54^{\prime \prime} \mathrm{W}$ \\
\hline Chubitayu & 1125 & Shuar & Paved road & 1.0 & $01^{\circ} 54^{\prime} 25^{\prime \prime} \mathrm{S}$ & $77^{\circ} 48^{\prime} 46^{\prime \prime} W$ \\
\hline Iskayaku & 60 & Kichwa & Trail & 3.0 & $01^{\circ} 22^{\prime} 04^{\prime \prime} \mathrm{S}$ & $77^{\circ} 38^{\prime} 05^{\prime \prime} \mathrm{W}$ \\
\hline Shiwa Kucha & 310 & Kichwa & Dirt road & 2.0 & $01^{\circ} 08^{\prime} 09^{\prime \prime} \mathrm{S}$ & $77^{\circ} 38^{\prime} 43^{\prime \prime} \mathrm{W}$ \\
\hline Jaime Roldós & 75 & Kichwa & River & 8.0 & $01^{\circ} 23^{\prime} 11^{\prime \prime} \mathrm{S}$ & $76^{\circ} 57^{\prime} 20^{\prime \prime} \mathrm{W}$ \\
\hline Killoalpa & 75 & Kichwa & River & 8.0 & $01^{\circ} 23^{\prime} 58^{\prime \prime} \mathrm{S}$ & $76^{\circ} 58^{\prime} 14^{\prime \prime} \mathrm{W}$ \\
\hline Nuevo San José & 150 & Kichwa & River & 8.0 & $01^{\circ} 22^{\prime} 26^{\prime \prime} \mathrm{S}$ & $76^{\circ} 56^{\prime} 25^{\prime \prime} \mathrm{W}$ \\
\hline Santa Cecilia & 150 & Kichwa & Dirt road & 3.5 & $01^{\circ} 30^{\prime} 012^{\prime \prime} \mathrm{S}$ & $77^{\circ} 28^{\prime} 59^{\prime \prime} \mathrm{W}$ \\
\hline Canelos & 2713 & Kichwa & Dirt road & 1.0 & $01^{\circ} 33^{\prime} 28^{\prime \prime} \mathrm{S}$ & $77^{\circ} 45^{\prime} 02^{\prime \prime} \mathrm{W}$ \\
\hline
\end{tabular}

Source: Survey data (see text). 
Table 2

Variables and descriptive statistics for mestizo colonists, Kichwas and Shuar

\begin{tabular}{|c|c|c|c|c|c|}
\hline Variable & Description & Overall & Colonists & Kichwa & Shuar \\
\hline \multicolumn{6}{|l|}{ Dependent variables } \\
\hline Farm self-employment & Farm self-employment as principal work $(0 / 1)$ & 0.254 & 0.134 & 0.351 & 0.230 \\
\hline Environmental income & Environmental income as principal work $(0 / 1)$ & 0.073 & 0.061 & 0.070 & 0.085 \\
\hline Farm wage employment & Farm wage employment as principal work $(0 / 1)$ & 0.216 & 0.207 & 0.250 & 0.197 \\
\hline Non-farm self-employment & Non-farm wage employment as principal work $(0 / 1)$ & 0.082 & 0.085 & 0.063 & 0.092 \\
\hline $\begin{array}{l}\text { Non-farm wage employment } \\
\text { Individual-level variables }\end{array}$ & Non-farm wage as principal work $(0 / 1)$ & 0.373 & 0.513 & 0.266 & 0.396 \\
\hline Age & Individual's age (years) & 39.6 & 41.2 & 41.1 & 38.2 \\
\hline Female & Individual is female $(0 / 1)$ & 0.23 & 0.30 & 0.16 & 0.25 \\
\hline Education & Completed years of formal education (years) & 8.5 & 7.9 & 7.9 & 9.6 \\
\hline Colonist & Individual is colonist $(0 / 1)$ & 0.232 & - & - & - \\
\hline Kichwa & Individual is Kichwa $(0 / 1)$ & 0.350 & - & - & - \\
\hline Shuar & Individual is Shuar $(0 / 1)$ & 0.416 & - & - & - \\
\hline \multicolumn{6}{|l|}{ Household-level variables } \\
\hline Household size & Number of household members & 4.5 & 3.7 & 5.3 & 4.2 \\
\hline Share of women & Share of women in the household & 0.33 & 0.36 & 0.29 & 0.36 \\
\hline Share of children & Share of children $(<15$ years) in the household & 0.32 & 0.28 & 0.39 & 0.28 \\
\hline Wealth & Wealth index & 0.196 & 1.505 & -0.655 & 0.391 \\
\hline Credit & Household has received credit & 0.36 & 0.37 & 0.21 & 0.48 \\
\hline Cultivated land & Area under crops and pasture (ha) & 5.77 & 6.55 & 3.12 & 8.57 \\
\hline Land in forest & Land in forest (ha) & 36.0 & 13.5 & 59.3 & 30.4 \\
\hline \multicolumn{6}{|l|}{ Community-level variables } \\
\hline Piped water & Share of households with access to piped water & 0.50 & 0.63 & 0.49 & 0.43 \\
\hline Distance to urban areas & $\begin{array}{l}\text { time needed to reach the closest town with more } \\
\text { than } 10,000 \text { people (minutes) }\end{array}$ & 154 & 50 & 232 & 140 \\
\hline
\end{tabular}

Note: (0/1) identifies dummy variables.

logit-since it does not assume independence of irrelevant alternatives (IIA) (Wooldridge, 2002). We thus use a model of the following form:

$$
\begin{aligned}
P_{i}^{c} & =\operatorname{Pr}\left(\text { WORKING }=c \mid X_{i j k}, H_{j k, k}\right) \\
& =F\left(X_{i j k} \beta_{1}^{c}+H_{j k} \beta_{2}^{c}+P_{k} \beta_{3}^{c}\right),
\end{aligned}
$$

where $P^{c}$ is the likelihood of an individual $i$ working in category of employment $c$, with $c$ indicating any of the five work categories described above. $X, H$ and $P$ are vectors of individual, household and community characteristics, described later. $\beta_{1}, \beta_{2}$ and $\beta_{3}$ are the coefficients of the characteristics that constitute the explanatory or independent variables, showing the size and direction of effects.

\subsection{Variables and hypotheses and descriptive statistics}

Table 2 presents the definitions and descriptive statistics of the variables used in the analysis. The dependent variables of interest are five binary variables indicating whether an individual has either farm self-employment, environmental income, farm wage employment, non-farm self-employment or non-farm wage employment as his/her principal source of income, referred to here as main source of employment. The dependent variables are discussed further below in the descriptive analysis. The list of explanatory variables includes sets of individual, household and community characteristics. All the variables included here are expected to affect whether the person works and in what type of work, and hence are relevant in a livelihood theory framework as used here.

Individual characteristics include age, gender, years of formal education and ethnicity. A priori, one expects older persons, males vs. females, and indigenous persons more than migrant mestizo colonists to engage in agricultural activities on the farm, other things equal. Educated people are hypothesized to be more likely to take part in (better paying) non-farm jobs than those with less education. In rural Ecuador, gender plays an important role in the division of labor (Martínez, 2000). Since there are 85 women
(23\%) in the sample, we include a dummy variable taking the value of 1 if the person is a woman to control for the effect of gender on the outcome variables. Thus we anticipate that women are less likely to be involved in farm work (at least among mestizos), off-farm agricultural work, and environmental work activities, and more likely to engage in non-farm self-employment (often managing small local stores called tiendas). On the other hand, it is not clear a priori whether women are more likely to work in non-farm work than men when other variables are controlled for. As ethnicity may relate to different cultural values and tastes for various types of work in ways which are not obvious, two dummy variables indicating whether an individual is Kichwa or Shuar are included in the model., with colonists as the reference group $(=0)$. It is hypothesized that colonists work more off-farm than the indigenous, so the coefficients for the latter are expected to be negative.

Among the household variables, we include household size and the proportions or shares of women and children in the household separately to control for possible effects of household composition on individual decisions concerning principal type of employment. Thus women are less likely to engage in off-farm work when they have more children, which is adequately proxied by the number of children in the household. Household economic conditions or wealth is proxied by a wealth index, which is the first principal component of household assets. ${ }^{3}$ We prefer this methodology because, in distinction from simple count indices, which assign equal values to every asset, it gives higher weight to assets which provide more information about household wealth (Filmer and Pritchett, 2001). There is also the possibility that reverse causality and therefore simultaneity exists between wealth and an individual's livelihood choice, resulting in endogeneity. However, this is not an issue as it would be with current income, since wealth is a construct based upon assets

\footnotetext{
${ }^{3}$ Possession of a radio, TV, cell phone, computer, gas stove, refrigerator, chainsaw, spray pump, car, motorcycle, solar panel and rifle. The first principal component accounts for $29 \%$ of the variation.
} 
accumulated over a number of years prior to the survey. This makes it essentially pre-determined, greatly reducing the likelihood of reverse causality and simultaneity. Substantively, wealth provides a means to overcome entry barriers to some jobs and to non-farm self-employment (license fees, equipment and machinery acquisition, among others). Lack of access to credit can be a major drawback for creating and operating a rural business (Lanjouw and Lanjouw, 2001). Since there is no direct way to measure access other than use of credit, to capture the effect of access to credit, a dummy variable equal to 1 if the household has received a loan and zero otherwise is included. Lack of land or having little land is hypothesized to be an important driver of participation in off-farm employment (Vasco and Vasco, 2012). To control for this, the natural logarithm of the amount of land under crops plus pasture (to reduce the effect of outliers) is included in the model. Additionally, and given the importance of forest income for some people's livelihoods in the Amazon, the natural logarithm of land in forest is added to the specification, and expected to especially affect participation in environmental income generating activities.

Finally, we consider the effects of (available) community-level or contextual factors on the type of employment. First, infrastructure and services are hypothesized to be key determinants of the creation and development of rural businesses (Lanjouw, 1999; Vasco, 2013). They affect the likelihood of someone having a nonfarm business, but also in the aggregate, create non-farm employment opportunities for others in the area. Non-farm employment is likely linked to distance by road to the nearest town (see Barbieri et al. (2009), on the Northern Ecuadorian Amazon). To take these factors into account, the share of households with access to piped water -estimated at the community level- and the time needed to get from the local community to the closest town of more than 10,000 people (which in all cases was Puyo) are included in the model, following some preliminary investigation. Availability of piped water is likely to be correlated with location and possibly also ethnicity (share of colonist households with piped water is higher than that of indigenous). We checked for collinearity in the model, but the variance test did not indicate any worrisome covariance (inflating factors all below 2.5).

Table 2 also shows mean values for all variables for the three ethnic groups. Overall, the Shuar are younger and better educated than the Kichwa and colonists. Colonist women are more likely to be engaged in income generating activities than indigenous women, which could be related to cultural norms in indigenous communities or to colonist farms being on roads. Kichwa households are larger than their Shuar and colonist peers. It is known from other work (Bremner et al., 2009; Bilsborrow et al., 2004) that fertility rates of the Kichwa and Shuar are very high and higher than those of colonist women in the Amazon. A possible explanation for Shuar households nevertheless being smaller than the Kichwa could be that more Shuar have migrated to local towns or even back to their provinces of origin in the southern Amazon. Kichwa homes have fewer women but more children than their Shuar and colonist counterparts. In terms of land use, the Shuar have more land in crops and pasture than the colonists and more than double that of the Kichwa, which is related to the Shuar engaging in cattle ranching far more than any other indigenous group in the Ecuadorian Amazon (see Gray and Bilsborrow, 2008). Partly as a result of this, the Kichwa have double the amount of land in forest compared to Shuar communities, and quadruple that of colonists. Finally, comparing values for contextual variables, colonist households have more access to piped water and also live closer to the provincial capital, Puyo, with the Kichwa farther away than the Shuar.

\section{Results and discussion}

\subsection{Descriptive analysis}

Table 2 above shows the proportions of persons who depend on each of the five types of work for their main source of income by ethnic group. Colonists have the lowest shares of farm selfemployment and environmental income and the highest share of non-farm wage employment (51.3\%). This is not surprising since they are generally settled closer to urban areas, and also on or near main roads (see Fig. 1). Few colonists (13.4\%) have farm selfemployment as their main source of income. Smaller farm sizes and more land in cultivation and pasture also restrict the possibility of agricultural land expansion. Farm wage labor is also important, being the principal income source for $20 \%$.

Most Kichwa obtain income mainly from farm self-employment, which is not surprising since they reside farther away from Puyo. A quarter of the Kichwa earn their livelihoods selling labor to other farms, while a similar proportion have non-farm wage employment as their main source of income. Both environmental income and nonfarm self-employment have shares below $10 \%$.

Almost a quarter of the Shuar earn their income principally from agriculture, while $8.5 \%$ have environmental income as their largest source, higher than for colonists and Kichwa households. 20\% of the Shuar engage in agricultural wage labor, which together with data for the Kichwa, reflects the existence of an emerging wage labor market among indigenous peoples. This is a bit surprising since indigenous peoples in the Amazon are known to meet extra household labor needs mostly via exchange labor (Lu, 2001). Nevertheless, $31 \%$ of indigenous households report hiring agricultural labor the year preceding the survey.

Table 3 shows average annual income by category of employment and ethnic group. Agriculture and "environmental income" are higher for Shuar than for colonists and Kichwa. Earlier literature (Rudel et al., 2002a, 2002b) note that over time more Shuar engage in commercial agriculture (naranjilla production and cattle ranching) and exploitation of natural resources (especially timber). Income from non-farm self-employment is considerably higher for Shuar than for colonists or Kichwa. This is consistent with prior research (Lanjouw, 1999) showing that the Shuar are more likely to participate in high productivity non-farm self-employment. One possible explanation is that half of the Shuar participating in nonfarm self-employment are chainsaw owners or timber dealers (often illegal), businesses that offer higher returns than most other business activities, such as a tienda, cooking meals and handicrafts. These figures show that non-farm activities in Shuar territories are closely linked to timber so that non-farm employment does not necessarily involve a reduction in pressure on natural resources.

Although the share of colonists engaged in farm selfemployment is the lowest among the three ethnic groups, onfarm agricultural income still accounts for a larger portion (36\%) of household income than for the two indigenous populations (Table 4). Colonists engage in cash crop production and cattle ranching, which is far more profitable than subsistence agriculture practiced by most indigenous peoples. Environmental income is also important, accounting for $18 \%$ of colonists' income, which may reflect that, in spite of living closer to urban areas and having less land in forest, colonist households still rely on timber exploitation to balance their budgets. In spite of being the main income source for half of the individual colonists, nonfarm wage employment accounts only for a quarter of colonist households' total income.

The opposite occurs for the Kichwa who, in spite of being mostly engaged in farm self-employment, earn their livelihoods principally from non-farm wage employment. A possible explanation is that the Kichwa practice mostly low-value subsistence agriculture 
Table 3

Average annual individual earnings by employment category and ethnic group (US \$).

\begin{tabular}{|c|c|c|c|c|}
\hline & Colonist & Kichwa & Shuar & All ethnic groups \\
\hline Farm self-employment & 1307 (1789) & $1160(1153)$ & $2016(2732)$ & $1517(2027)$ \\
\hline Environmental income & $836(1312)$ & $824(1301)$ & $1110(2302)$ & $962(1747)$ \\
\hline Farm wage employment & $2226(1807)$ & $1593(872)$ & $1453(641)$ & 1663 (1079) \\
\hline Non-farm self-employment & $3407(3184)$ & $2741(1555)$ & $5564(6576)$ & $3936(4631)$ \\
\hline Non-farm wage employment & $5751(3060)$ & $5902(3604)$ & $5060(3650)$ & $5440(3345)$ \\
\hline Total earned income & $4136(3373)$ & $3383(3114)$ & 3851 (3847) & $3790(3998)$ \\
\hline
\end{tabular}

Note: Standard deviations in parentheses.

Table 4

Share of households' income by ethnic group (column percentages).

\begin{tabular}{lllll}
\hline & Colonist & Kichwa & Shuar & Total \\
\hline Farm self-employment & 36 & 30 & 32 & 32 \\
Environmental income & 18 & 11 & 17 & 15 \\
Farm wage employment & 14 & 14 & 17 & 15 \\
Nonfarm self-employment & 6 & 7 & 6 & 7 \\
Nonfarm wage employment & 25 & 38 & 28 & 31 \\
\hline
\end{tabular}

and dedicate small areas to agriculture. Environmental income accounts for only $11 \%$ of Kichwa household total income. Since Kichwa communities are farther away from roads and urban centers, this may in turn make it difficult to extract and market forest products.

Farm self-employment is the principal income source for Shuar households (32\% of total income). Environmental income accounts for $17 \%$ of Shuar households' income. This figure is similar to that of colonists and indicate that Shuar and colonist households are more dependent on forest resources than Kichwa. Non-farm wage employment is the second largest income source for Shuar households accounting for $28 \%$ of total income. There are no major differences in the shares of farm wage employment and nonfarm self-employment among the three ethnic groups. Overall, Table 4 reports more similarities among colonists and Shuar households than between Kichwa and Shuar households.

Table 5 shows types of occupation by ethnic group, which requires some explanation. A quarter of colonists work in the public sector (24\%) while another third are engaged in low remunerative non-farm wage jobs (domestic servant, bricklayer and driver). Most Kichwa are school teachers $(50 \%)$ or (other) public sector employees (19\%), which are among the better paid jobs in the area. This may explain why non-farm wage employment is the first source of income for Kichwa homes despite the fact that most have farm self-employment as their principal income source. The Shuar have a more diversified non-farm job portfolio than the Kichwa, with teaching, public service, army and domestic service the most frequent choices.

It is interesting to reflect on the role of public investment in the Amazon as it employs 33, 70 and 53\% of the colonist, Kichwa and

Table 5

Type of occupation by ethnic group (\%).

\begin{tabular}{lrccr}
\hline & Colonist & Kichwa & Shuar & Total \\
\hline Domestic servant & 14.3 & 0.0 & 10.6 & 8.8 \\
Soldier & 2.4 & 0.0 & 10.6 & 5.4 \\
School teacher & 11.9 & 50.0 & 33.3 & 31.3 \\
Public employee & 23.8 & 19.4 & 12.1 & 17.0 \\
Bricklayer & 9.5 & 2.8 & 6.1 & 7.5 \\
Carpenter & 2.4 & 2.8 & 4.5 & 3.4 \\
Chainsaw operator & 4.4 & 0.0 & 6.1 & 2.7 \\
Driver & 9.5 & 0.0 & 0.0 & 2.7 \\
Guide & 0.0 & 5.6 & 1.5 & 2.0 \\
Mechanic & 0.0 & 5.6 & 0 & 1.4 \\
Janitor & 4.8 & 5.6 & 0 & 2.7 \\
Other & 17.0 & 8.2 & 15.2 & 15.1 \\
\hline
\end{tabular}

Shuar non-farm workers, respectively. Recent government investments in education and the expansion of public service jobs in rural areas may have played a significant role in shaping employment patterns in the Amazon. A similar picture is depicted in Steward (2007) case study of Carvão in the Brazilian Amazon, where Federal Government decentralization created high-paying (teachers, agricultural extension agents) and low-paying jobs (nurses, teacher assistants, school cooks, security guards), which reduced interest in farming. As mentioned above, significant governmental investments ${ }^{4}$ in the last decade increased the demand for public and private sector employees in the Amazon, though many of the qualified, better paid positions continue to be occupied by a floating population from other regions, leaving lowskilled jobs for local people. An exception to this is elementary school teachers, who account for 50 and $33 \%$ of the Kichwa and Shuar non-farm workers respectively, showing that school teacher is the only type of non-farm employment whose availability is not influenced by location or population density. A possible explanation is the implementation of the "Bilingual Intercultural Education System," which prioritizes cultural and linguistic development among indigenous peoples of Ecuador (SENPLADES, 2014).

\subsection{Multivariate results: effects of independent variables}

Statistical results from the multinomial probit model are presented in Table 6. First, the effects of the explanatory or independent variables on employment in general are described, looking at individual variables, household variables and then contextual factors. We are, of course, especially interested in the effects of ethnicity, as that is something not examined in a cross-cultural study in the Amazon previously as far as we know.

To begin, age effects are absent once other variables are controlled for, which is a curious finding but shows it is mostly other factors linked to age that lead to different types of work (viz., education). In contrast, gender has significant effects on the main type of work: Being a woman significantly reduces the likelihood of a person's working on one's own farm as the principal income source by $21 \%$, which is consistent with previous results of Vasco et al. (2013) based on less detailed data for the Amazon region as a whole. Women are also 5\% less likely to work in environmental work, such as hunting, fishing and timber extraction, which are generally considered "men's work". On the other hand, gender has no significant effect on whether the person engages in off-farm agricultural work, or operating a non-farm business as the major source of income. The former shows that women as well as men engage in off-farm agricultural work, though women do this closer to their own farm. The latter is likely related to the small sample size of persons having a non-farm business ( $8 \%$ of the sample), since a common non-farm business is operating a small store or "tienda",

\footnotetext{
4 Transfers to regional and municipal governments in the Amazon increased from US \$ 927 million in the period 2000-2006 to US \$ 4213 million in the period
} 2007-2014 (SENPLADES, 2014). 
Table 6

Multinomial probit model, on the determinants of being engaged in the five possible work categories of on-farm and off-farm employment (marginal effects).

\begin{tabular}{|c|c|c|c|c|c|}
\hline & Farm self-employment & Environmental income & Farm wage employment & Non-farm self-employment & Non-farm wage employment \\
\hline \multicolumn{6}{|l|}{ Individual variables } \\
\hline Age & 0.004 & -0.003 & 0.004 & -0.001 & -0.003 \\
\hline Age squared & -0.000 & 0.000 & -0.000 & 0.000 & 0.000 \\
\hline Female $(0 / 1)$ & $-0.214^{* * *}$ & $-0.052^{* * *}$ & 0.049 & 0.303 & $0.186^{* *}$ \\
\hline Education & $-0.022^{* * *}$ & $-0.005^{* *}$ & $-0.024^{* * *}$ & $-0.011^{* * *}$ & $0.064^{* * *}$ \\
\hline Kichwa $(0 / 1)$ & $0.156^{* *}$ & -0.032 & 0.097 & -0.011 & $-0.210^{* * *}$ \\
\hline Shuar $(0 / 1)$ & 0.028 & -0.024 & 0.062 & 0.003 & -0.070 \\
\hline \multicolumn{6}{|l|}{ Household variables } \\
\hline Household size & 0.018 & -0.000 & -0.018 & 0.003 & -0.003 \\
\hline Share of women & $0.431^{* *}$ & -0.095 & $0.201^{* *}$ & -0.051 & -0.082 \\
\hline Share of children & 0.282 & -0.066 & $0.313^{* *}$ & $0.178^{* *}$ & -0.081 \\
\hline Wealth & -0.032 & $-0.022^{* * *}$ & $-0.035^{*}$ & $0.047^{* * *}$ & $0.042^{*}$ \\
\hline Credit $(0 / 1)$ & $0.112^{*}$ & 0.012 & $-0.098^{*}$ & 0.021 & -0.046 \\
\hline Cultivated land & $0.081^{* * *}$ & $0.009^{* *}$ & $-0.028^{* *}$ & $0.030^{* *}$ & $-0.093^{* * *}$ \\
\hline Land in forest & $-0.034^{* *}$ & $0.019^{* * *}$ & $-0.032^{* *}$ & 0.003 & $0.044^{* *}$ \\
\hline \multicolumn{6}{|l|}{ Community variables } \\
\hline Piped water & -0.026 & $-0.076^{* * *}$ & -0.086 & 0.026 & $0.162^{* *}$ \\
\hline Distance to urban areas & $0.085^{* *}$ & $0.025^{*}$ & -0.028 & $0.056^{* *}$ & $-0.087^{*}$ \\
\hline Number of observations & 365 & & & & \\
\hline Wald test $\chi^{2}$ & $278^{* * *}$ & & & & \\
\hline Log likelihood & -398.634 & & & & \\
\hline
\end{tabular}

Note: ${ }^{*}{ }^{* *}$ and ${ }^{* * *}$ stand for significance at the $0.1,0.05$ and 0.01 levels, respectively. (0/1) identifies dummy variables.

which is invariably done by women. Finally, being a woman strongly increases the likelihood of engaging in non-farm wage employment, discussed further below.

Not surprisingly, education has powerful effects on the main type of livelihood of a person, with each year of education increasing the likelihood of engaging in non-farm wage work by over $6 \%$ (so increasing completed years of schooling from 4 to 12 , or completed secondary school, would about double this probability). At the same time, each additional year of education reduces the likelihood of participation in each of the other four types of work. Of farm work (on one's own farm or someone else's) by $2.2-2.4 \%$, of self-employment by $1.1 \%$, and of work producing environmental income by $0.5 \%$. The effect on reducing having a non-farm business is different from earlier research for rural Ecuador as a whole (Elbers and Lanjouw, 2001; Lanjouw, 1999; Vasco, 2013), where it was concluded that education is positively correlated with the likelihood of owning a business compared to other economic activities. A possible explanation is that entrepreneurial activities in the rural Amazon (mainly operating a store, meal preparation, handicraft elaboration and timber-related activities) involve lowlevel technology, and hence do not require much education. Overall, these results for education are expected, albeit perhaps surprisingly strong in a region with only one small city and low technology economic activities.

Moving on to ethnicity, it also has some intriguing differences in effects. Thus the Kichwa are $16 \%$ more likely to have their main income source be on-farm agriculture than colonists (or Shuar), while at the same time they are $21 \%$ less likely to engage in nonfarm work. There are no differences in the effects of Kichwa vs. colonist in involvement in the other three work types as the main source of income. These findings reinforce the descriptive evidence of Table 4 and indicate that the Kichwa are the most dependent on agriculture and the least engaged in urban work, while the Shuar and colonists are virtually indistinguishable. This reinforces findings of other studies showing the Shuar are the most like colonists of the various indigenous groups in the Amazon region (e.g. Gray and Bilsborrow, 2008; Lu et al., 2012).

Moving on to the household variables, household size has no effects, in contrast to household age-sex composition. Thus the higher the proportion of women, the higher the probability of the person under study having farm self-employment or off-farm agricultural labor as his/her largest source of income. Agricultural labor is usually done close to home. The result for the proportion of children in the household -that a higher proportion is linked positively to the person being an agricultural laborer or working in self-employment-makes sense since those types of work are more compatible with child care, and tend to be close to home. Household assets as a proxy for wealth has a negative effect on the person seeking "environmental income" or working as a farm laborer, but a strong positive effect on engaging in non-farm self-employment. The former is consistent with earlier literature (Barbier, 2010) associating poverty with higher reliance on environmental resources, while the latter supports the view that persons in wealthier households are more likely to set up businesses, consistent with Reardon et al. (2006) who found better-off households more easily overcome "entry barriers" that non-farm self-employment entails.

The land variables have interesting effects on type of work also. Cultivated land is positively linked to the likelihood of participation in farm self-employment (more cultivated land means more time needed for on-farm work) and "environmental income" (those with more cultivated land are also likely to have more total land, including forested land). Having more land in cultivation also is linked to less working for others in farm or non-farm work, as hypothesized, but an increased likelihood of working in selfemployment. The latter is because farming and running a nonfarm business out of (usually) the house are complementary economic activities since they are usually done in close proximity. More land in forest, other things equal, is linked to having less land cultivated and hence a lower likelihood of working on one's own farm or in other low-income agricultural work, and instead more to environmental work (since much is based on the forest) and nonfarm work. This is consistent with research in the Northern Ecuadorian Amazon (Pichón, 1997a; Pichon and Bilsborrow, 1999), and suggests that non-farm wage earnings can relax pressures to clear forest to meet household needs. The direction of causation, however, is not clear, as more wealth in forested land may free up people to work away more (the coefficient being almost identical to that of wealth).

With regard to the contextual variables, environmental occupations linked to the forest are more likely in isolated communities where provision of services - proxied by the share of households 
with access to piped water- is limited. An increase of $10 \%$ in the share of households having access to piped water is associated with a reduction of $8 \%$ in the likelihood of an individual to obtain income from the environment. This is not a causal association, however, but an effect of location, which is supported by the coefficient for distance from Puyo. On the other hand, piped water is associated with a greater likelihood of non-farm work, which is mostly in urban areas where piped water is available Distance to the one significant urban area is only marginally negatively linked to non-farm work, but is positively linked to both working on one's own farm and selfemployment, as expected. These two contextual variables capture overlapping phenomena, though are not seriously collinear (see earlier in paper).

\section{Multivariate results by type of livelihood}

The discussion of the results above has presented the results showing differences in the effects of variables on the five types or categories of livelihoods. Here we summarize the results from the perspective of each type of livelihood, providing a brief typology of the main factors linked to each livelihood choice, beginning with the factors affecting work on one's own farm. Thus for "farm selfemployment", the person is statistically likely to be male, with low education, a larger share of adult women in the household, and to have a farm with more cultivated land and little forest land. The person is also likely to be Kichwa, and to live far from the one significant urban place, the provincial capital, Puyo.

Persons depending on "environmental income" as their main source of income also tend to be male, with low education but the share of women is not relevant, and have more land both in cultivation (complementary to extracting timber) similar characteristics but have more land in forest. They are also relatively far from Puyo, but have no infrastructure, a difference from those depending on income from their own farm work.

In terms of who works as farm wage laborers, these are persons with little education or land, and more likely from households with large proportions of women and children. At the macro level, these could be households in areas where population growth and resulting land subdivisions (Bilsborrow et al., 2004) have reduced plot sizes over time to a point where the land plots can no longer support livelihoods from agriculture. In any case, those with more land have less (need to engage in paid) work away from the household farm, whether in agriculture or not. Overall, these results are in agreement with earlier research (Vasco et al., 2013; Vasco and Vasco, 2012) concluding that farm wage employment is likely for land-constrained, uneducated people who also lack the financial capital to start a business or the human capital (education) to engage in much non-farm wage employment.

Moving on to non-farm self-employment, persons in this activity are likely to have significant land in cultivation, little education, a larger proportion of children in the household (childcare being often compatible with this work), wealth (to confront entry barriers for setting up a business), and to be far from Puyo. The latter is likely due to the fact that those living near urban areas find it easy to shop in stores in town, while those who reside farther away will tend to buy necessities when they run out, from a small local retail store or "tienda" ( $40 \%$ of the total number of businesses in the sample) rather than travel far to the main urban place, Puyo.

Finally, non-farm wage employment is perhaps the most interesting of the five livelihood approaches-both because it is likely to expand most with future economic development and because it already provides a large if not the largest proportion of household income for the three rural study populations (see Tables 3 and 4). Persons more likely to be engaged in non-farm wage employment tend to be female, with more years of education, and mestizo colonists or Shuar but not Kichwa. They are likely to have less land in cultivation than others, since that would absorb household labor, but more land in forest. They are likely to live closer to the urban area (Puyo) and to live in wealthier communities with more infrastructure, such as a piped water system serving most dwellings, which is consistent with previous studies (Elbers and Lanjouw, 2001; Lanjouw, 1999; Vasco and Vasco, 2012) highlighting the role of infrastructure in facilitating non-farm job opportunities in rural areas.

\section{Concluding remarks}

This study has analyzed the differences in livelihood choices of indigenous and migrant colonist households and the factors affecting these differences in Pastaza, Ecuador, one of the world's biodiversity hotspots in the Amazon basin. The results reveal that off-farm employment (mostly non-farm) is the main income source for $68 \%$ of the individuals in the sample and accounts on average for $53 \%$ of household income. Within off-farm employment, off-farm wage employment yields low earnings but and is the main income source for those with little land/assets or education. On the other hand, non-farm wage employment, which flourishes near urban areas, is engaged in especially by those with more education, especially women.

The notions of colonists using cropping and cattle ranching involving continuous clearing of forests over time and of indigenous peoples practicing subsistence agriculture and collecting forest products with little impact on the natural environment are no longer accurate, as increasingly more households have off-farm employment as their largest source of household income. This is likely due to both push factors, including scarcity of agricultural land due to population increase (Bilsborrow et al., 2004), which has led to subdivision of farms which has in turn driven people into offfarm employment, as well as pull factors, notably the generally higher earnings available in non-farm employment, which is partly due to the expansion of public sector employment due to the expanded role of the state in the region. These jobs are especially available to those with more education.

The findings in the paper lead to a challenging question: Does the expansion of non-farm employment have the potential to combine rural development with protection of the natural environment, a win-win policy? Certainly earnings from both nonfarm self-employment and non-farm wage employment are generally higher than those of farm work, which should in itself reduce pressures to clear forest to expand agriculture and extract timber. However, indiscriminately promoting non-farm selfemployment may include extraction, transport and trade of timber, particularly in areas with remaining forest cover and road networks that facilitate transporting timber to markets. A second concern has to do with dependence on public sector employment, which overall offers the highest earnings within non-farm wage employment and has some potential to absorb rural surplus labor. First, further expansion of public employment depends partly on the country's economic growth and capacity to generate jobs, including for more teachers to increase the supply of educated members of the labor force, both males and females. But there is a Catch-22 here, as this in turn requires more public resources, to train more teachers and pay them to go to rural areas (such as the Amazon) to educate more of the rural population at the secondary education level, to increase the supply of persons qualified to take advantage of the higher demand for such more educated workers generated by continuing economic growth. The absorption of more such workers in urban areas in turn adds to economic growth.

In this context, policies should also be oriented to promote environmentally friendly entrepreneurial activities in the Amazon 
region, such as ecotourism, community-based tourism, scientific tourism, and processing and industrialization of renewable forest products. These entrepreneurial ventures have the potential, properly managed and taxed, to create benefits for local populations, especially indigenous populations. Training in tourism and hospitality and making available credit for community-based initiatives could help in achieving this goal, but more research and experimental pilot projects would be useful to explore practical uses of the extraordinary Amazonian biodiversity and ancestral knowledge as potential income sources for indigenous peoples. Finally, even though an important share of the sample population in this project is already involved in non-farm wage employment, many of the better and more qualified positions in both the public and private sectors are currently filled by a floating population coming from other regions of Ecuador, reflecting the limited qualifications of the vast majority of the labor force in throughout the Amazon. In this regard, increasing investment in higher education would help to not only improve human capital but should also significantly increase income levels of the rural population. For the indigenous populations especially, it is not access to basic (primary) education-which is widely available in almost all indigenous communities- but access to much better quality primary and secondary education (and increasingly in the future, university level education) that is needed.

\section{Acknowledgements}

Field work was funded by the Universidad Estatal Amazónica at Puyo. Carlos Wampash, Luis Chongo, Juvenal Espín and Shiram Vargas assisted with the data collection. We are grateful to three anonymous reviews and the editor for most helpful comments on an earlier version.

\section{References}

Anderson, D., Leiserson, M.W., 1980. Rural nonfarm employment in developing countries. Econ. Dev. Cult. Change 28, 227-248.

Angelsen, A., Jagger, P., Babigumira, R., Belcher, B., Bauch, S., Börner, J., Smith-Hall, C. Wunder, S., 2014. Environmental income and rural livelihoods: a globalcomparative analysis. World Dev. 64, S12-S28.

Barbier, E.B., 2010. Poverty, development, and environment. Environ. Dev. Econ. 15, 635-660.

Barbieri, A., Bilsborrow, R., Pan, W., 2005. Farm household lifecycles and land use in the Ecuadorian Amazon. Popul. Environ. 27, 1-27.

Barbieri, A.F.v., Carr, D.L., Bilsborrow, R.E., 2009. Migration within the frontier: the second generation colonization in the Ecuadorian Amazon. Popul. Res. Policy 28, 291-320.

Bass, M.S., Finer, M., Jenkins, C.N., Kreft, H., Cisneros-Heredia, D.F., McCracken, S.F., Pitman, N.C.A., English, P.H., Swing, K., Villa, Gorky, Fiore, A.D., Voigt, C.C., Kunz, T.H., 2010. Global conservation significance of Ecuador's Yasuní National Park. PlosOne 5.

Berdegué, J., Ramírez, E., Reardon, T., Escobar, G., 2001. Rural nonfarm employment and incomes in Chile. World Dev. 29, 411-425.

Bilsborrow, R., Barbieri, A., Pan, W., 2004. Changes in population and land use over time in the Ecuadorian Amazon. Acta Amaz. 34, 635-647.

Bremner, J., Bilsborrow, R., Feldacker, C., Holt, F.L., 2009. Fertility beyond the frontier: indigenous women, fertility, and reproductive practices in the Ecuadorian Amazon. Popul. Environ. 30, 93-113.

Cavendish, W., 2003. How Do Forest Support, Insure and Improve the Livelihoods of the Rural Poor? a Research Note. CIFOR, Bogor.

Corral, L., Reardon, T., 2001. Rural nonfarm incomes in Nicaragua. World Dev. 29, 427-442.

ECORAE, 2003. Zonificación Ecológica Economica del ECORAE, Quito, Ecuador.

Elbers, C., Lanjouw, P., 2001. Intersectoral transfer, growth and inequality in rural Ecuador. World Dev. 29, 481-496.

Ellis, F., 1993. Peasant Economics: Farm Households and Agrarian Development, second ed. Cambridge University Press, Cambridge.

Ellis, F., 2000. The determinants of rural livelihood diversification in developing countries. J. Agric. Econ. 51, 289-302.

Escobal, J., 2001. The determinants of nonfarm income diversification in rural Peru. World Dev. 29, 497-508.

Ferreira, F., Lanjouw, P., 2001. Rural nonfarm activities and poverty in the Brazilian Northeast. World Dev. 29, 509-528.

Filmer, D., Pritchett, L., 2001. Estimating wealth effects without expenditure data-or tears: an application to educational enrollments in states of India.
Demography 38, 115-132.

Goodman, R., Kish, L., 1950. Controlled selection - a technique in probability sampling. J. Am. Stat. Assoc. 45, 350-372.

Gray, C., Bilsborrow, R., 2008. Indigenous land use in the Ecuadorian Amazon: a cross-cultural and multilevel analysis. Hum. Ecol. 36, 97-109.

Hicks, J.F., Daly, H.E., Davis, S.H., de Freitas, M.d.L., 1990. Ecuador's Amazon Region Development Issues and Options. World Bank, Washington D.C, p. 41.

INEC., 2010. Censo de Población y Vivienda 2010. Quito, Ecuador.

Isgut, A., 2004. Non-farm income and employment in rural Honduras: Assessing the role of locational factors. J. Dev. Stud. 40, 59-86.

Jara Alba, C., Umpierrez de Reguero, S., 2014. Evolución del sector público ecuatoriano desde 1998 a 2013. Rev. Enfoques 12, 131-148.

Jonasson, E., Helfand, S.M., 2010. How important are locational characteristics for rural non-agricultural employment? Lessons from Brazil. World Dev. 38 727-741.

Kish, L., 1965. Survey Sampling. Wiley, New York.

Lanjouw, J.O., Lanjouw, P., 2001. The rural non-farm sector: issues and evidence from developing countries. Agric. Econ. 26, 1-23.

Lanjouw, P., 1999. Rural Nonagricultural employment and poverty in Ecuador. Econ. Dev. Cult. Change 48, 91-122.

Laszlo, S., 2005. Self-employment earnings and returns to education in rural Peru. J. Dev. Stud. 41, 1247-1287.

Lu, F., 2001. The common property regime of the Huaorani Indians of Ecuador: implications and challenges to conservation. Hum. Ecol. 29, 425-447.

Lu, F., Bilsborrow, R.E., Ona, A.I., 2012. Modos de Vivir y Sobrevivir: Un Estudio Transcultural de Cinco Etnias en la Amazonia Ecuatoriana. ABYA-YALA, Quito, Ecuador.

Mainville, N., Webb, J., Lucotte, M., Davidson, R., Betancourt, O., Cueva, E. Mergler, D., 2006. Decrease of soil fertility and release of mercury following deforestation in the Andean Amazon, Napo River Valley, Ecuador. Sci. Total Environ. 368, 88-98.

Martínez, L., 2000. Economías Rurales: Actividades No Agrícolas. CAAP, Quito, Ecuador.

Murphy, L., 2001. Colonist farm income, off-farm work, cattle, and differentiation in Ecuador's Northern Amazon. Hum. Organ. 60, 68-79.

Murphy, L., Bilsborrow, R., Pichón, F., 1997. Poverty and prosperity among migrant settlers in the Amazon rainforest frontier of Ecuador. J. Dev. Stud. 34, 35-66.

Myers, N., Mittermeier, R., Mittermeier, C., Fonseca, G., Kents, J., 2000. Biodiversity hotspots for conservation priorities. Nature 403, 853-858.

Pichón, F., 1997a. Colonist land-allocation decisions, land use, and deforestation in the Ecuadorian Amazon frontier. Econ. Dev. Cult. Change 45, 707-744.

Pichón, F., 1997b. Settler households and land-use patterns in the amazon frontier: farm-level evidence from Ecuador. World Dev. 25, 67-91.

Pichón, F., Bilsborrow, R., 1999. Land use systems, deforestation, and demographic factors in the humid tropics: farm-level evidence from Ecuador. In: Bilsborrow, R., Hogan, D. (Eds.), Population and Deforestation in the Humid Tropics. IUSSP, Liege, Belgium, pp. 175-207.

Prado Córdova, J., Wunder, S., Smith-Hall, C., Börner, J., 2013. Rural income and forest reliance in highland Guatemala. Environ. Manag. 51, 1034-1043.

Pastaza, Prefectura de, 2012. Plan de Desarrollo de la Provincia de Pastaza al año 2025.

Reardon, T., Berdegué, J., Barrett, C.B., Stamoulis, K., 2006. Household income diversification into rural nonfarm activities. In: Haggblade, S., Hazell, P. Reardon, T. (Eds.), Transforming the Rural Nonfarm Economy. Johns Hopkins University Press, Baltimore.

Reardon, T., Edward Taylor, J., Stamoulis, K., Lanjouw, P., Balisacan, A., 2000. Effects of non-farm employment on rural income Inequality in developing countries: an investment perspective. J. Agric. Econ. 51, 266-288.

Rudel, T.K., Bates, D., Machinguiashi, R., 2002a. Ecologically noble Amerindians? cattle ranching and cash cropping among shuar and colonists in Ecuador. Lat. Am. Res. Rev. 37, 144-159.

Rudel, T.K., Bates, D., Machinguiashi, R.,2002b. A tropical forest transition? agricultural change, outmigration, and secondary forests in the Ecuadorian Amazon. Ann. Assoc. Am. Geogr. 92, 87-102.

SENPLADES, 2012. Proceso de desconcentración del Ejecutivo en los niveles administrativos de planifiación. SENPLADES, Quito, Ecuador.

SENPLADES, 2013. Plan Nacional del Buen Vivir 2013-2017. SENPLADES, Quito, Ecuador.

SENPLADES, 2014. Proyectos Emblemáticos-Pastaza.

Singh, I., Squire, L., Strauss, J., 1986. A survey of agricultural household models: recent findings and policy implications. World Bank Econ. Rev. 1, 149-179.

Steward, A., 2007. Nobody farms here anymore: livelihood diversification in the Amazonian community of Carvao, a historical perspective. Agric. Hum. Values 24, 75-92.

VanWey, L., Vithayathil, T., 2013. Off-farm work among rural households: a case study in the Brazilian Amazon. Rural. Sociol. 78, 29-50.

Vasco, C., 2013. Migration, remittances and entrepreneurship: the case of rural Ecuador. Migr. Int. 7, 37-64.

Vasco, C., Herrera, B., Vargas, S., Arias, R., 2013. Empleo Agrícola y no Agrícola en la Amazonía Ecuatoriana. Ecuad. Debate 90, 141-151.

Vasco, C., Vasco, D., 2012. El Empleo Rural no Agrícola en Ecuador. Ecuad. Debate 86.

Wooldridge, J.M., 2002. Econometric Analysis of Cross Section and Panel Data, 2 ed. MIT. Press, Cambridge, MA.

Wunder, S., Angelsen, A., Belcher, B., 2014. Forests, livelihoods, and conservation: Broadening the empirical Base. World Dev. 64, S1-S11. 